\title{
Occurrence and Assessment of Chemical Contaminants in Drinking Water in Tunceli, Turkey
}

\author{
Veysel Demir ${ }^{1}$ and Sezai Ergin ${ }^{2}$ \\ ${ }^{1}$ Department of Environmental Engineering, Faculty of Engineering, Tunceli University, 62000 Tunceli, Turkey \\ ${ }^{2}$ Department of Communicative Diseases, Environment and Public Health, Health Directorate of Tunceli, 62000 Tunceli, Turkey \\ Correspondence should be addressed to Veysel Demir; veyseldemir@tunceli.edu.tr
}

Received 15 May 2013; Revised 25 July 2013; Accepted 26 July 2013

Academic Editor: Carlos Alberto Martínez-Huitle

Copyright (c) 2013 V. Demir and S. Ergin. This is an open access article distributed under the Creative Commons Attribution License, which permits unrestricted use, distribution, and reproduction in any medium, provided the original work is properly cited.

The objective of this study was to analyze drinking water samples from 21 sites in the city center and seven municipalities of Tunceli, Turkey, in order to determine the presence of nitrate, nitrite, fluoride, bromate, pesticides, polycyclic aromatic hydrocarbons (PAHs), trihalomethanes (THMs), and some other chemicals. In all locations, the concentrations of chemicals investigated were below the permissible limits set by local and international organizations for drinking water. Low levels of nitrate $(4.79 \pm 4.20 \mathrm{mg} / \mathrm{L})$, fluoride $(0.11 \pm 0.08 \mathrm{mg} / \mathrm{L})$, and THMs $(6.63 \pm 5.14 \mu \mathrm{g} / \mathrm{L})$ were detected in all locations. A low level of tetra, chloroethane, which is suspected to be a human carcinogen, was also detected in 8 locations in the range of $0.26-0.43 \mu \mathrm{g} / \mathrm{L}$. These contaminants may pose adverse health effects or minimum hazard due to long-term exposure. In all locations, bromate, benzene, total PAH, 1-2 dichloroethane, vinyl chloride, acrylamide, and epichloridine levels in drinking water samples were under detection limits.

\section{Introduction}

Wastewater discharges, agricultural runoff, uncontrolled discharges or leakage from industrial plants or landfill sites, and chemical accidents and disasters can contaminate ground and surface water $[1,2]$. These contaminations become an increasing problem for drinking water supplies [3]. The possible long-term effects of chronic exposure to substances present in drinking water, even at low concentrations, are one of the major concerns over water quality and public health $[4,5]$. Lifetime exposure to chemicals such as pesticides, polycyclic aromatic hydrocarbons (PAHs), trihalomethanes (THMs), and trace elements in drinking water through ingestion, inhalation, and dermal contact (i.e., showering and bathing) may pose risks to human health [6]. Contaminated water can cause serious diseases, such as reproductive, cardiovascular, and neurological diseases or various cancers $[6,7]$.

There are international and national regulations to control the quality of drinking water. Some chemical parameters including nitrate, nitrite, fluoride, undesirable organic compounds (benzene and PAHs), pesticides and pesticide residues, bromate, and THMs with specified upper limits are strictly controlled for drinking water. Nitrate is one of the most common inorganic contaminants detected in drinking water throughout the world. A high nitrate concentration in drinking water can cause methemoglobinemia in infants and in the stomachs of adults $[8,9]$. Also, a high level of nitrate in drinking water is recognized as a risk factor for thyroid dysfunction in vulnerable population groups [10]. Nitrate can be reduced to nitrite, resulting in the formation of nitrosamines, which are known to be carcinogenic [11]. The World Health Organization (WHO) [12] and the Turkish Standard Institute (TSI) [13] have set the standard nitrate level in drinking water to $50 \mathrm{mg} \mathrm{NO}^{3-} / \mathrm{L}$, while the US Environmental Protection Agency's (EPA) standard is $10 \mathrm{mg} \mathrm{N} / \mathrm{L}$ [14]. Fluoride is a necessary element for human health, and a moderate amount of fluoride intake is an effective way of reducing caries among children and adults. However, excessive fluoride intake through drinking water or food results in dental and skeletal fluorosis; furthermore, nonskeletal phase damage such as parathyroid, kidney, and liver is observed [15]. Fluorine is highly reactive and is found naturally as $\mathrm{CaF}_{2}$. It is an essential component of minerals like topaz, fluorite, fluorapatite, cryolite, phosphorite, theorapatite, and so forth. 
[16]. Though drinking water is the major contributor (75$90 \%$ of daily intake), other sources of fluoride poisoning are food, industrial exposure, drugs, cosmetics, and so forth [17]. The TSI [13] and EPA have set the standard fluoride level in drinking water at $1.5 \mathrm{mg} / \mathrm{L}$, and the WHO's safe limit is $1.0 \mathrm{mg} / \mathrm{L}[18]$.

Throughout the world, pesticides including insecticides, fungicides, and herbicides, and others are used for vector control and agricultural purposes. Because of their widespread consumption, pesticides and their degradation products spread throughout the environment and contaminate the soil, water, and air [19]. Chemical classes of pesticides include organochlorine compounds, carbamates, organophosphates, and chlorophenoxy compounds. Many pesticides are persistent and bioaccumulative in the environment. Severe disorders in the reproductive, nervous, and immune systems and some chronic diseases including cancer can occur if the human body has extended exposure to pesticides [20]. Pesticides can leach into surface and ground waters; therefore, they are likely to be found in drinking water. Because of their widespread use and acute, long-term toxicity to humans, several agencies have derived drinking water guidelines for some pesticides [21]. The European Union (EU) established a list of 33 priority substances to be controlled in water through Directive no. 2008/105EC in 2008, with a third of the list being pesticides [22, 23].

PAHs occur widely in the environment, and they are very slow to degrade due to the high stability and complexity of the PAHs' molecular structure [24]. The water sources were polluted by many types of PAHs through anthropogenic and natural inputs or biological conversion of fossil fuel products. The presence of PAHs in drinking water threatens human health in the form of mutagenic, carcinogenic, and toxicological effects [25]. Therefore, many of these compounds are listed as priority pollutants by the EPA and the EU [26]. Concentrations of PAHs exceeding $10 \mu \mathrm{g} / \mathrm{L}$ suggested that the water was heavily contaminated [27]. The EU's and WHO's guidelines recommended that the total concentration of six specified PAHs should not exceed $200 \mathrm{ng}^{-1}$ for domestic drinking water [28].

During water treatment, chloride is the most widely used, cost-effective technique for disinfecting drinking water in order to protect the public from waterborne diseases and to control or prevent the regrowth of microorganisms and biofilm formation in the distribution system [29]. Nevertheless, chloride is a relatively unstable chemical, and available chlorine reacts with natural organic matters and inorganic substances in water, causing the formation of various chlorination byproducts such as THMs [30]. The frequently formed THM compounds are chloroform (trichloromethane, TCM), bromodichloromethane (BDCM), dibromochloromethane (DBCM), and bromoform (tribromomethane, TBM) [31]. These THM species and other chlorinated substances, such as 1,2-di/tri/tetra/chloroethane, are considered to be toxic, accumulative, and persistent in the environment and probable carcinogens for human health in several epidemiological studies [32, 33]. Different countries set limits for THM and other chlorinated substances in drinking water. The limits set are
$40 \mu \mathrm{g} / \mathrm{L}$ for chloroform, $15 \mu \mathrm{g} / \mathrm{L}$ for bromodichloromethane, $10 \mu \mathrm{g} / \mathrm{L}$ for trichloroethane and tetrachloroethane, $3 \mu \mathrm{g} / \mathrm{L}$ for 1,2-dichloroethane, and $100 \mu \mathrm{g} / \mathrm{L}$ for total THMs [31, 34].

Some other chemical pollutants that are also monitored in drinking water according to EU Directive 98/93 on drinking water have the following guideline values: benzene $(1.0 \mu \mathrm{g} / \mathrm{L})$, which is widely used in products containing plastics, rubber, resins, and synthetic fabrics like nylon and polyester; epichlorohydrin $(0.1 \mu \mathrm{g} / \mathrm{L})$, which is used for making glycerine, plastics, and other polymers, some of which are used as coagulant aids in water treatment; vinyl chloride $(0.5 \mu \mathrm{g} / \mathrm{L})$, which is used in polyvinyl chloride piping in drinking water distribution systems [35]; and acrylamide, which is used in acrylamide based polymeric coagulant aids used in water treatment $(0.1 \mu \mathrm{g} / \mathrm{L})$ - all of which are suspected to be human carcinogens [3]. The EPA's maximum contamination level goals in drinking water for benzene, vinyl chloride, epichlorohydrin, and acrylamide are zero [14].

In Turkey, there is a national monitoring program for determining the pollutants in drinking water sources and implementing remediation recommendations based on these results. The health directorate of each city monitors drinking water quality in its area. But there are limited number of studies evaluating the results of these monitoring programs, and some results stay in the database of the local authorities without further evaluation. This study was undertaken with the Health Directorate of Tunceli in order to assess the concentration of some chemicals in drinking water samples taken from 21 different locations in the city and towns of Tunceli, Turkey. During the investigation, the contents of nitrate, nitrite, fluoride, bromate, benzene, total $\mathrm{PAH}$, total pesticide, total THMs, 1,2-di/tri/tetra/chloroethane, vinyl chloride, acrylamide, and epichloridine concentrations were analyzed to determine water quality in these locations. This study will further clarify the importance of monitoring these parameters during evaluation of water quality in the city of Tunceli and benefit monitoring authorities and the city during implementation of water treatment applications in the studied areas.

\section{Materials and Methods}

2.1. Study Site. The city of Tunceli is located in eastern Turkey. The local terrain delimits the region and sets it apart from the surrounding area. There is no heavy industrial or agricultural activity in this region; the city center and seven municipalities of Tunceli depend on agriculture, husbandry, apiculture, and tourism. Water sources are abundant in the area due to rain and heavy snowfall in the mountains, which seeps into the ground or flows into the rivers. Most of the public waterworks consist simply of water sources, a chlorination unit, and a transport pipe. The quality of the drinking water, especially microbial contamination [36] in the rural areas of Tunceli, cannot be ensured in some cases. In this study, water samples were collected in 21 different locations in the city center and seven municipalities of Tunceli during 2011. The sampling sites were illustrated in Figure 1. 


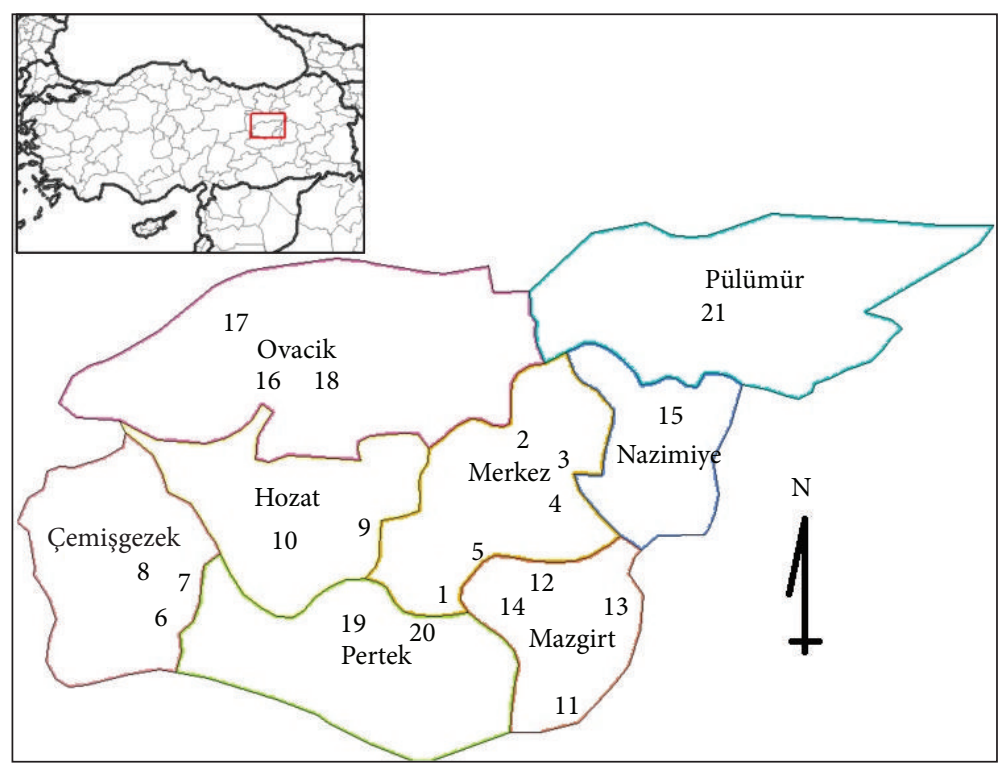

FIGURE 1: Locations of sampling sites.

2.2. Sampling. Drinking water samples were collected by the Health Directorate of Tunceli from residential drinking water according to correct sampling techniques in order to analyze their chemical contents. Five liters of each water sample was taken in polyethylene plastic containers that had been previously washed with concentrated nitric acid. All samples were transported in cooled containers to the laboratory of the Health Directorate of Erzurum and were refrigerated at $4^{\circ} \mathrm{C}$ until analysis, which was carried out within 48 hours of sampling.

2.3. Analysis. Drinking water samples were analyzed in the laboratory of the Health Directorate of Erzurum. For nitrate, nitrite, fluorite, and bromate, the Dionex ICS-5000 Ion Chromatography System with the EPA Method 300.1 was used. For pesticides including organophosphates and chlorophenoxy compounds, gas chromatography (Perkin Elmer/Clarus 500) with the EPA Methods 8141A was used. For pesticides including organochlorine compounds, gas chromatography (Agilent GC-7890A) with EPA Methods 8081B and for acrylamide and pesticides including carbamates triple quadrupole liquid chromatograph mass spectrometer (Shimadzu LC-MSMS/8030) with EPA Methods 8361A and 531.1, respectively, were used.

The levels of total PAHs including benzo[b]fluoranthene, benzo[k]fluoranthene, benzo[g,h,i]perylene, indeno[1,2,3cd]pyrene, and benzo[a]pyrene were analyzed using high performance liquid chromatography (Thermo TSP, HPLC) with the EPA Method 550.1. THMs, benzene, 1,2$\mathrm{di} /$ tri/tetra/chloroethane, and other chemical pollutants (epichloridine, vinyl chloride, and tetrachloroethane) in drinking water samples were measured by purge and trap GC/MS system including Agilent 7820A GC, Agilent 5975 MS system, and The Eclipse 4660 Purge-and-Trap Sample Concentrator using the EPA Method 524.2 and TS 9266 EN ISO 10301.

\section{Results and Discussion}

The water demand in Tunceli is supplied mostly by groundwater. Abundant groundwater supplies are the most costeffective and viable means for fulfilling the needs of the present population. There is no municipal water treatment plant for drinking water; for each location, groundwater is collected in a storage tank and disinfected by chlorination. In recent years, the city substituted most of the old sewer mains, especially old asbestos-cement pipes, with new PVC pipes. In the seven municipalities of Tunceli, the majority of people drink tap water, but in the city center, the ratio of people drinking bottled water increases with the education and income level. City wastewater was discharged at 9 different points into Uzuncayir Dam Lake without any treatment processes. Boztug et al. (2012) [37] investigated the water quality of this lake by identifying the water's physicchemical characteristics, and they concluded that Uzuncayir Dam Lake has good water quality and no serious pollution problem. In 2013, Tunceli's first wastewater treatment facility for the city center was put into test operations. But the other seven municipalities of Tunceli do not have any wastewater treatment facilities, and they discharge wastewater directly into rivers or lakes.

Concentrations of the studied chemicals in the drinking water sampling locations of the city center and municipalities of Tunceli, Turkey, were summarized in Table 1. The mean of fluoride concentration in all water sampling sites was calculated as $0.11 \pm 0.08 \mathrm{mg} / \mathrm{L}$. In the present study, all samples were below the permissible limit $(1.5 \mathrm{mg} / \mathrm{L})$ set by the TSI [13] in fluoride concentration. The highest level of fluoride was observed in the city center of Mazgirt at $0.28 \mathrm{mg} / \mathrm{L}$. Considering that water is the major source of fluoride intake in humans, the recommended minimum value of fluoride in drinking water associated with the maximum level of dental caries protection and the minimum level of dental 
TABLE 1: Concentrations of the studied chemicals in the drinking water sampling locations of the city center and municipalities of Tunceli, Turkey.

\begin{tabular}{|c|c|c|c|c|c|c|c|c|}
\hline No. & Locations & Municipalities & Nitrate $(\mathrm{mg} / \mathrm{L})$ & Fluoride $(\mathrm{mg} / \mathrm{L})$ & $\begin{array}{l}\text { T. pesticides } \\
(\mu \mathrm{g} / \mathrm{L})\end{array}$ & $\mathrm{THMs}^{*}(\mu \mathrm{g} / \mathrm{L})$ & $\begin{array}{c}\text { Chloroform } \\
(\mu \mathrm{g} / \mathrm{L})\end{array}$ & $\mathrm{TCE}^{* *}(\mu \mathrm{g} / \mathrm{L})$ \\
\hline 1 & Burmageçit & Merkez $^{* * *}$ & 3.48 & 0.07 & $\mathrm{UDL}^{* * * *}$ & 3.30 & 3.30 & UDL \\
\hline 2 & Cumhuriyet & Merkez & 4.70 & 0.04 & UDL & 5.07 & 5.07 & 0.26 \\
\hline 3 & Esentepe & Merkez & 1.39 & 0.13 & UDL & 9.92 & 9.92 & UDL \\
\hline 4 & Kanoglu & Merkez & 2.21 & 0.16 & UDL & 5.04 & 3.99 & UDL \\
\hline 5 & Kopuzlar & Merkez & 1.65 & 0.10 & UDL & 2.34 & 2.34 & 0.30 \\
\hline 6 & Akçapinar & Çemisgezek & 8.26 & 0.13 & UDL & 7.23 & 7.23 & UDL \\
\hline 7 & Payamdüzü & Çemisgezek & 1.78 & 0.02 & UDL & 4.13 & 4.13 & UDL \\
\hline 8 & Tepebasi & Çemisgezek & 13.11 & 0.26 & 0.027 & 4.09 & 4.09 & UDL \\
\hline 9 & Devriscemal & Hozat & 1.46 & 0.01 & UDL & 13.40 & 11.58 & UDL \\
\hline 10 & Yenidogdu & Hozat & 2.74 & 0.07 & 0.042 & 2.95 & 2.95 & UDL \\
\hline 11 & Akpazar & Mazgirt & 16.22 & 0.16 & UDL & 10.05 & 10.05 & 0.37 \\
\hline 12 & Bulgurcular & Mazgirt & 4.22 & 0.08 & UDL & 3.01 & 3.01 & 0.34 \\
\hline 13 & Center & Mazgirt & 9.30 & 0.28 & UDL & 19.30 & 12.53 & UDL \\
\hline 14 & Darikent & Mazgirt & 2.74 & 0.22 & 0.015 & UDL & 4.55 & 0.43 \\
\hline 15 & Center & Nazimiye & 2.92 & 0.02 & UDL & 3.17 & 3.17 & UDL \\
\hline 16 & Çakmakli & Ovacik & 0.28 & 0.11 & UDL & 12.99 & 12.99 & UDL \\
\hline 17 & Pasadüzü & Ovacik & 8.25 & 0.15 & UDL & 6.35 & 6.35 & 0.37 \\
\hline 18 & Pulur & Ovacik & 2.04 & 0.01 & UDL & 4.94 & 2.70 & UDL \\
\hline 19 & Camikebir & Pertek & 6.06 & 0.04 & UDL & 16.46 & 5.61 & 0.30 \\
\hline 20 & Sogukpinar & Pertek & 6.62 & 0.11 & UDL & 3.16 & 3.16 & 0.37 \\
\hline 21 & Center & Pülümür & 1.11 & 0.04 & UDL & 2.42 & 2.42 & UDL \\
\hline
\end{tabular}

${ }^{*}$ Trihalomethanes.

${ }^{* *}$ Tetrachloroethane.

${ }^{* * *}$ City center.

**** Under detection limit.

fluorosis is considered to be approximately $0.5 \mathrm{ppm}[12,38]$, and concentrations of fluoride lower than $0.5 \mathrm{mg} / \mathrm{L}$ have shown to intensify the risk of tooth decay [39]. Additionally, an extremely low level of fluoride $(<0.28 \mathrm{mg} / \mathrm{L})$ in drinking water which may cause fluoride deficiency among the inhabitants of these locations was observed in most sampling locations. Water fluoridation which is the controlled addition of fluoride to a public water supply could be advised to local authorities for preventing tooth decay.

Nitrate and nitrite are important indicators of water pollution. In Tunceli, the main sources of nitrogen are domestic and animal wastes and nitrogen-rich fertilizers. Nitrate levels ranged from a minimum of $0.28 \mathrm{mg} / \mathrm{L}$ in Ovacik, Cakmakli, to a maximum of $16.22 \mathrm{mg} / \mathrm{L}$ in Mazgirt, Akpazar. Nitrite values were detected $\leq 0.08 \mathrm{mg} / \mathrm{L}$ in all locations. These values are lower than $50 \mathrm{mg} / \mathrm{L}$ of nitrate and $3 \mathrm{mg} / \mathrm{L}$ of nitrite, the acceptable values according to the TSI's [13] and WHO's [12] standards for drinking water quality in public water systems. The mean of nitrate concentration in all water sampling sites $(4.79 \pm 4.20 \mathrm{mg} / \mathrm{L})$ and nitrite values $(\leq 0.08 \mathrm{mg} / \mathrm{L})$ were measured in all sampling sites. Many studies also investigated national nitrate and nitrite levels in drinking water. Similar unpolluted groundwater in Finland with simple treatment in the water plant is used as drinking water, and its nitrate range
$(0.05-1.19 \mathrm{mg} / \mathrm{L})$ is much lower than the values in this study. Finnish drinking water's nitrite level was below the detection limit of $0.01 \mathrm{mg} / \mathrm{L}$ [40]. Therefore, even a simple treatment in the water plant can increase water quality in Tunceli. Cidu et al. (2011) [41] studied drinking water quality in Italy and determined that Italian tap water's nitrate level ranged from $<0.1$ to $11 \mathrm{mg} / \mathrm{L}$. In Italy, a limit of $10 \mathrm{mg} / \mathrm{L} \mathrm{NO}^{3-}$ has been recommended for the water destined to infants [41, 42]. Some drinking water samples in our study showed $\mathrm{NO}^{3-}$ higher than $10 \mathrm{mg} / \mathrm{L}$ (Table 1), which may pose adverse health effects due to long-term exposure, especially in the infants of these locations.

The prescribed limit set by the TSI [13] for THMs in drinking water is $150 \mu \mathrm{g} / \mathrm{L}$. The mean concentration of total THMs $(6.63 \pm 5.14 \mu \mathrm{g} / \mathrm{L})$ in all water sampling sites mainly includes chloroform, which is the most commonly occurring THM in drinking water, and very small amounts of bromoform, dibromochloromethane, and bromodichloromethane, all of which were measured in these 21 locations. These values are below the prescribed limits of domestic [13] and international guidelines [12] for specified contamination levels of drinking water, and the results did not show an indication of pollution hazards, given the toxicity of these chemicals. Maximum concentrations were determined in 
Mazgirt-Merkez, Pertek-Camikebir, Hozat-Derviscemal, and Ovacık-Cakmakli as $19.3,16.5,13.4$, and $13.0 \mu \mathrm{g} / \mathrm{L}$, respectively. The concentrations of THMs found in Tunceli tap water were much less than the concentration reported for other Turkish cities such as Ankara, Izmir, and Cankırı [6, 43, 44].

Pesticide contamination in drinking water samples from Tunceli was assessed also. Total pesticides in 18 locations were below the detection limit, and in 3 locations, low concentrations of total pesticides were detected in the range of $0.015-0.042 \mu \mathrm{g} / \mathrm{L}$. In one location, the organochlorine pesticide dieldrin, which was banned in the US in the 1980s, was detected in a low concentration of $0.015 \mu \mathrm{g} / \mathrm{L}$. Also, the organochlorine insecticide alpha endosulfan, which was banned in several countries due to its acute toxicity and endocrine effects, was detected in one location with a low concentration of $0.027 \mu \mathrm{g} / \mathrm{L}$. The EU sets standards for pesticides in drinking water at $0.1 \mu \mathrm{g} / \mathrm{L}$ for each active ingredient and $0.5 \mu \mathrm{g} / \mathrm{L}$ for the sum of all pesticides [21]. Although these obtained values are quite low and below the recommended values, the presence of dieldrin and endosulfan in drinking water should be monitored regularly, since these chemicals may pose adverse health effects or minimum hazard to the inhabitants of these locations due to long-term exposure.

Bromate, benzene, total polycyclic aromatic hydrocarbons (PAHs) including benzo[a]pyrene, benzo(b) fluoranthene, benzo(k) fluoranthene, benzo[ghi]perylene, indeno[1,2,3-cd]pyrene, and other chemical pollutants such as 1,2-di/trichloroethane, epichloridine, vinyl chloride, and acrylamide also were not detected in all drinking water samples. Since there is a strong correlation between an increase in urbanization, industrialization and traffic density and high levels of PAHs in the water [24], it was expected not to detect any PAHs in these sampling stations. A low level of tetrachloroethane, which is suspected to be carcinogenic, was detected in 8 locations in the range of $0.26-0.43 \mu \mathrm{g} / \mathrm{L}$; these values were also lower than permissible limits of $10 \mu \mathrm{g} / \mathrm{L}$ set by EU Directive 98/93 for drinking water [34].

\section{Conclusions}

This study investigated the potential contamination levels of drinking water in the regions of Tunceli, Turkey, while paying special attention to pesticides, PAHs, THMs, and some other organic and inorganic chemicals. Some of these chemicals were detected in all drinking water samples, but none of the studied parameters exceeded the WHO guideline values [12] or the Turkish [13], American [14], or European [22] standards. The study results showed that the people living in Tunceli do not bear significant health risks especially due to exposure to pesticides, PAHs, THMs, and benzene in the drinking water.

\section{Acknowledgments}

This study is funded by the Health Directorate of Tunceli. Special thanks are due to the directors of these institutions for their support and to the reviewers for their useful and constructive comments.

\section{References}

[1] F. X. R. Van Leeuwen, "Safe drinking water: the toxicologist's approach," Food and Chemical Toxicology, vol. 38, no. 1, supplement, pp. S51-S58, 2000.

[2] N. C. Yildirim, N. Yildirim, O. Kaplan, and N. Tayhan, "Evaluation of chemical and microbiological contamination levels in drinking water samples collected from towns in Tunceli, Turkey," International Journal of Agriculture and Biology, vol. 12, no. 6, pp. 957-960, 2010.

[3] M. Schriks, M. B. Heringa, M. M. E. van der Kooi, P. de Voogt, and A. P. van Wezel, "Toxicological relevance of emerging contaminants for drinking water quality," Water Research, vol. 44, no. 2, pp. 461-476, 2010.

[4] J. E. Marcovecchio, S. E. Botte, and R. H. Freije, "Heavy metals, major metals, trace elements," in Handbook of Water Analysis, L. M. Nollet, Ed., pp. 275-311, CRC Press, London, UK, 2nd edition, 2007.

[5] C. J. Wyatt, C. Fimbre, L. Ro Mo, R. O. Mendez, and M. Grijalva, "Incidence of heavy metal contamination in water supplies in Northern Mexico," in Environmental Research, vol. 762, pp. 114119, 1998.

[6] E. Caylak, "Heath risk assessment for trace metals, polycyclic aromatik hydrocarbons and trihalomethanes in drinking water of Cankırı, Turkey," E-Journal of Chemistry, vol. 94, pp. 19761991, 2012.

[7] E. Caylak, M. Aytekin, and I. Halifeoglu, "Antioxidant effects of methionine, $\alpha$-lipoic acid, $\mathrm{N}$-acetylcysteine and homocysteine on lead-induced oxidative stress to erythrocytes in rats," Experimental and Toxicologic Pathology, vol. 60, no. 4-5, pp. 289-294, 2008.

[8] A. M. Fan, "Nitrate and nitrite in drinking water: a toxicological review," in Encyclopedia of Environmental Health, pp. 137-145, 2011.

[9] X. Zhao, L. Chen, and H. Zhang, "Nitrate and ammonia contaminations in drinking water and the affecting factors in Hailun, northeast China," Journal of Environmental Health, vol. 757, pp. 28-34, 2013.

[10] P. D. Gatseva and M. D. Argirova, "High-nitrate levels in drinking water may be a risk factor for thyroid dysfunction in children and pregnant women living in rural Bulgarian areas," International Journal of Hygiene and Environmental Health, vol. 211, no. 5-6, pp. 555-559, 2008.

[11] A. Ayala, L. O. Leal, L. Ferrer, and V. Cerdà, "Multiparametric automated system for sulfate, nitrite and nitrate monitoring in drinking water and wastewater based on sequential injection analysis," Microchemical Journal, vol. 100, no. 1, pp. 55-60, 2012.

[12] WHO: World Health Organization, Guidelines for Drinkingwater Quality, 4th edition, 2011, http://apps.who.int/iris/bitstream/10665/44584/1/9789241548151_eng.pdf.

[13] TS-266, Water Intended for Human Consumption, Turkish Standards Institution, Ankara, Turkey, 2005, (Turkish).

[14] U.S. Environmental Protection Agency, Drinking Water Standards and Health Advisories, Government Printing Office, Washington, DC, USA, 2012.

[15] H.-R. Li, Q.-B. Liu, W.-Y. Wang et al., "Fluoride in drinking water, brick tea infusion and human urine in two counties in Inner Mongolia, China," Journal of Hazardous Materials, vol. 167, no. 1-3, pp. 892-895, 2009.

[16] R. Singh and R. C. Maheshwari, "Defluoridation of drinking water-a review," Indian Journal of Environmental Protection, vol. 21, no. 11, pp. 983-991, 2001. 
[17] M. Meenakshi, V. K. Garg, K. Kavita, R. Renuka, and A. Malik, "Groundwater quality in some villages of Haryana, India: focus on fluoride and fluorosis," Journal of Hazardous Materials, vol. 106, no. 1, pp. 85-97, 2004.

[18] M. Meenakshi and R. C. Maheshwari, "Fluoride in drinking water and its removal," Journal of Hazardous Materials, vol. 137, no. 1, pp. 456-463, 2006.

[19] Z. Zulin, H. Huasheng, W. Xinhong, L. Jianqing, C. Weiqi, and $\mathrm{X}$. Li, "Determination and load of organophosphorus and organochlorine pesticides at water from Jiulong River Estuary, China," Marine Pollution Bulletin, vol. 45, no. 1-12, pp. 397-402, 2002.

[20] L. Ritter, N. C. I. Goushleff, T. Arbuckle, D. Cole, and M. Raizenne, "Addressing the linkage between exposure to pesticides and human health effects - research trends and priorities for research," Journal of Toxicology and Environmental Health $B$, vol. 9, no. 6, pp. 441-456, 2006.

[21] M. Younes and H. Galal-Gorchev, "Pesticides in drinking water-a case study," Food and Chemical Toxicology, vol. 38, no. 1, supplement, pp. S87-S90, 2000.

[22] European Commission, Decision No. 2008/105/EC Amending Directive 2000/60/EC. Off. J. Eur. Commun. L 327 1, 2008.

[23] E. Herrero-Hernández, M. S. Andrades, A. Álvarez-Martín, E. Pose-Juan, M. S. Rodríguez-Cruz, and M. J. Sánchez-Martín, "Occurrence of pesticides and some of their degradation products in waters in a Spanish wine region," Journal of Hydrology, vol. 486, pp. 234-245, 2013.

[24] S. Sanches, C. Leitão, A. Penetra et al., "Direct photolysis of polycyclic aromatic hydrocarbons in drinking water sources," Journal of Hazardous Materials, vol. 192, no. 3, pp. 1458-1465, 2011.

[25] WHO, "Polynuclear aromatic hydrocarbons in drinking-water," in Background Document for Development of WHO Guidelines for Drinking-Water Quality, World Health Organization, Geneva, Switzerland, 2003.

[26] L. Zhu, Y. Chen, and R. Zhou, "Distribution of polycyclic aromatic hydrocarbons in water, sediment and soil in drinking water resource of Zhejiang Province, China," Journal of Hazardous Materials, vol. 150, no. 2, pp. 308-316, 2008.

[27] Y. Chen, L. Zhu, and R. Zhou, "Characterization and distribution of polycyclic aromatic hydrocarbon in surface water and sediment from Qiantang River, China," Journal of Hazardous Materials, vol. 141, no. 1, pp. 148-155, 2007.

[28] M. I. Badawy and M. A. Emababy, "Distribution of polycyclic aromatic hydrocarbons in drinking water in Egypt," Desalination, vol. 251, no. 1-3, pp. 34-40, 2010.

[29] M. A. El-Shafy and A. Grünwald, "THM formation in water supply in south Bohemia, Czech Republic," Water Research, vol. 34, no. 13, pp. 3453-3459, 2000.

[30] WHO, "Trihalomethanes in drinking water," in Guidelines for Drinking Water Quality, World Health Organization, Geneva, Switzerland, 2005.

[31] J. Kuivinen and H. Johnsson, "Determination of trihalomethanes and some chlorinated solvents in drinking water by headspace technique with capillary column gas-chromatography," Water Research, vol. 33, no. 5, pp. 1201-1208, 1999.

[32] N. S. Chary and A. R. Fernandez-Alba, "Determination of volatile organic compounds in drinking and environmental waters," Trends in Analytical Chemistry, vol. 32, pp. 60-75, 2012.

[33] IRIS, Integrated Risk Information System of United States, Environmental Protection Agency, 2009.
[34] Commission of the European Communities, Proposal for a Council Directive, 95/C 131/03, 1995.

[35] R. K. Walter, P.-H. Lin, M. Edwards, and R. E. Richardson, "Investigation of factors affecting the accumulation of vinyl chloride in polyvinyl chloride piping used in drinking water distribution systems," Water Research, vol. 45, no. 8, pp. 26072615, 2011.

[36] V. Demir, N. Yildirim, N. C. Yildirim, S. Ergin, and A. Cumurcu, "Evaluation of bacteriological quality of drinking water in the City Center of Tunceli, Turkey," Journal of Pure and Applied Microbiology, vol. 71, pp. 785-789, 2013.

[37] D. Boztug, T. Dere, N. Tayhan et al., "Physico-chemical characteristics of Uzuncayir Dam Lake Tunceli and water quality," Adıyaman Üniversitesi Fen Bilimleri Dergisi, vol. 22, pp. 93-106, 2012 (Turkish).

[38] Z. Mandinic, M. Curcic, B. Antonijevic et al., "Fluoride in drinking water and dental fluorosis," Science of the Total Environment, vol. 408, no. 17, pp. 3507-3512, 2010.

[39] J. Fawell, Fluoride in Drinking-Water, WHO DrinkingWater Quality Series, IWA Publishing, London, UK, 2006, http://www.who.int/water_sanitation_health/publications/fluoride_drinking_water_full.pdf.

[40] O. M. Zacheus and P. J. Martikainen, "Physicochemical quality of drinking and hot waters in Finnish buildings originated from groundwater or surface water plants," Science of the Total Environment, vol. 204, no. 1, pp. 1-10, 1997.

[41] R. Cidu, F. Frau, and P. Tore, "Drinking water quality: comparing inorganic components in bottled water and Italian tap water," Journal of Food Composition and Analysis, vol. 24, no. 2, pp. 184-193, 2011.

[42] GURI, Decreto legislativo 29 dicembre 2003. attuazione della direttiva n. 2003/40/CE. Gazzetta Ufficiale della Repubblica Italiana n. 302 del 31-12-2003, Roma, Italy, 38-42 in Italian, 2003.

[43] B. Tokmak, G. Capar, F. B. Dilek, and U. Yetis, "Trihalomethanes and associated potential cancer risks in the water supply in Ankara, Turkey," Environmental Research, vol. 96, no. 3, pp. 345352, 2004.

[44] P. Kavcar, M. Odabasi, M. Kitis, F. Inal, and S. C. Sofuoglu, "Occurrence, oral exposure and risk assessment of volatile organic compounds in drinking water for İzmir," Water Research, vol. 40, no. 17, pp. 3219-3230, 2006. 

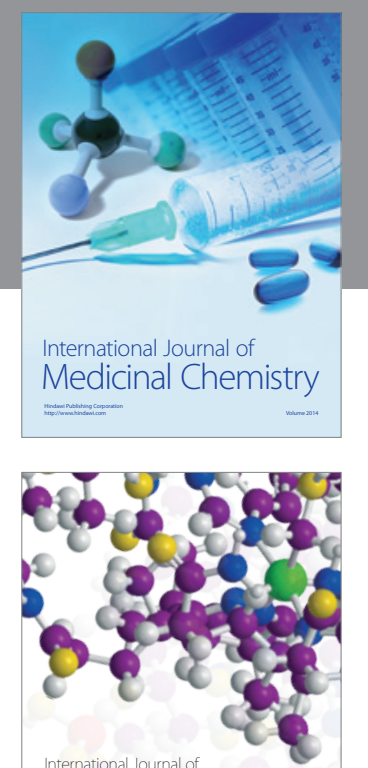

\section{Carbohydrate} Chemistry

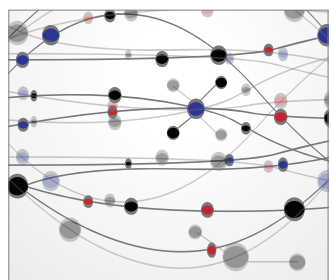

The Scientific World Journal
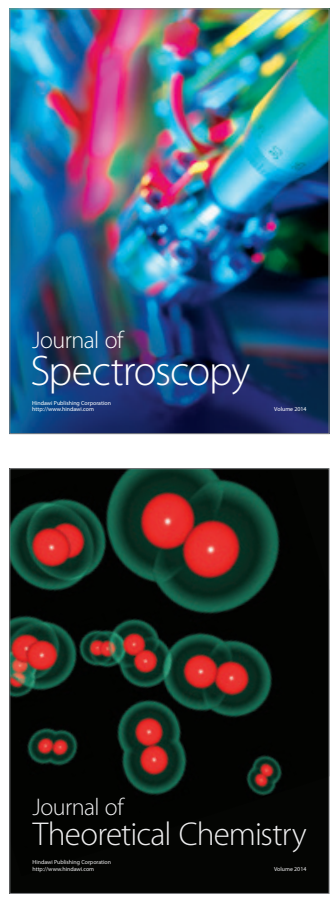
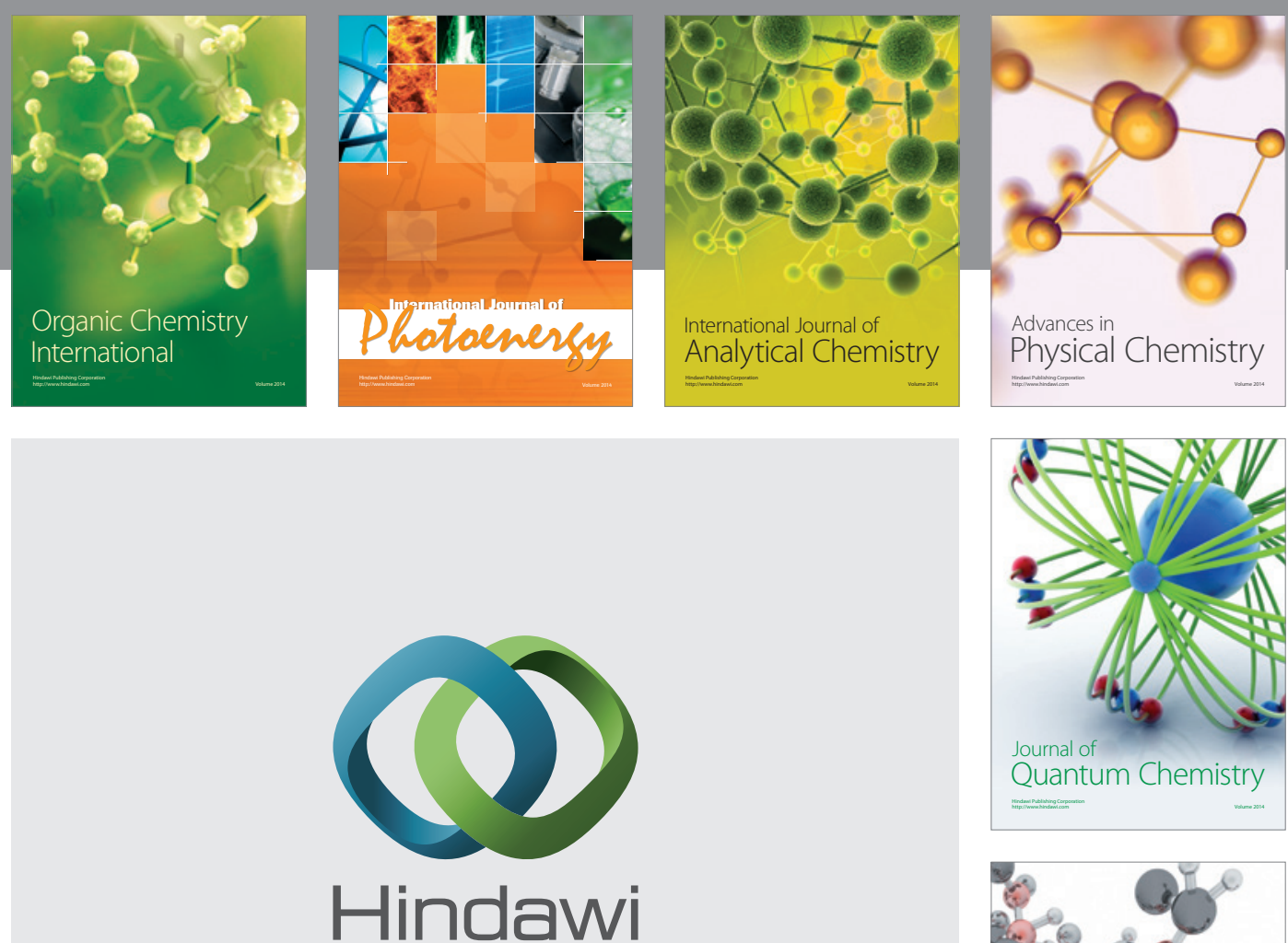

Submit your manuscripts at

http://www.hindawi.com

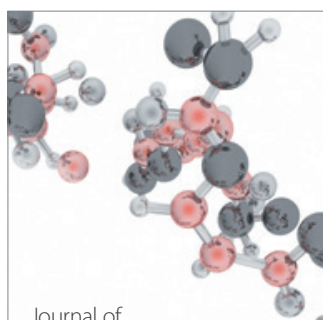

Analytical Methods

in Chemistry

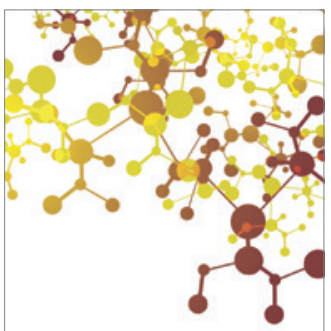

Journal of

Applied Chemistry

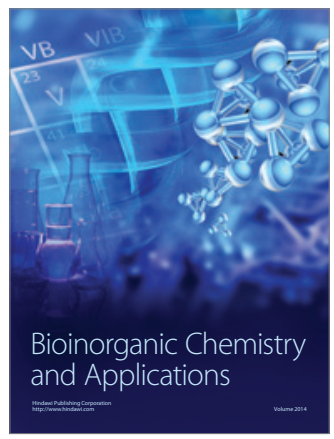

Inorganic Chemistry
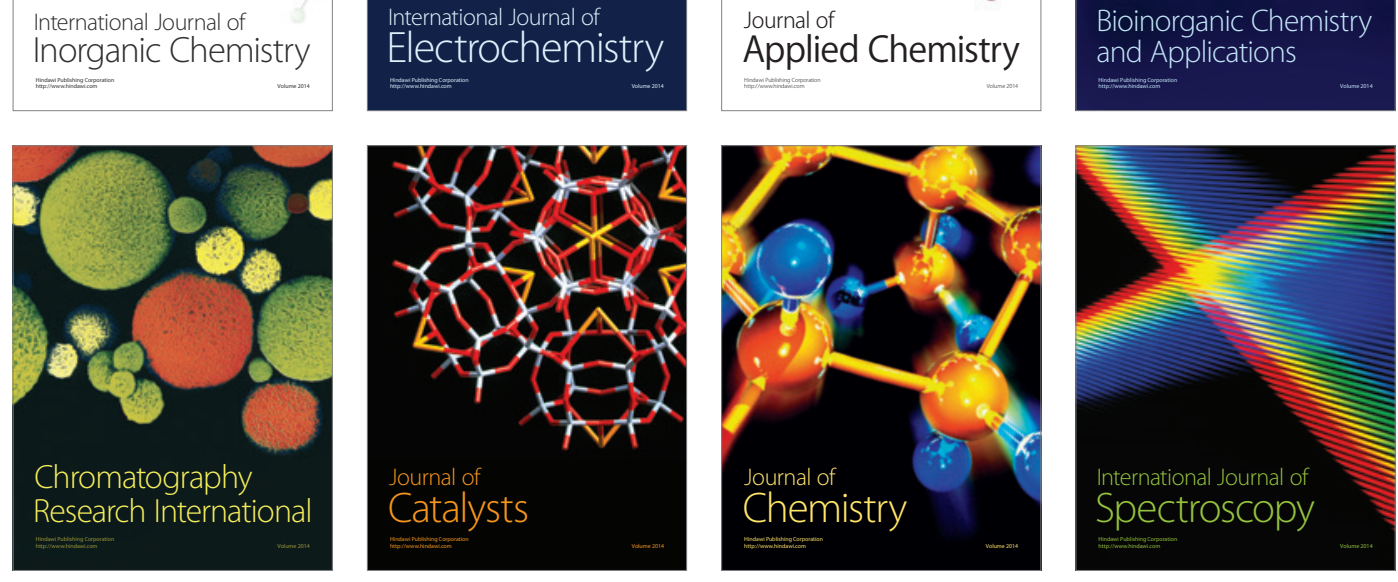